\title{
MEASURES OF RESIDENTIAL ENERGY ACCESS IN MEXICO, 2008-2014
}

\author{
Rafael PEREZ1, Benjamin WIDNER ${ }^{2}$ \\ ${ }^{1}$ University of Texas at El Paso, El Paso, United States \\ ${ }^{2}$ New Mexico State University, Las Cruces, United States \\ Corresponding author e-mail: rperezpena@utep.edu
}

\begin{abstract}
The concept of energy access in developing countries, such as Mexico, encompasses the accessibility to reliable fuels for heating, cooking, and lighting purposes while reducing coal and firewood consumption. This paper suggests residential energy access indicators by applying accessibility theory and estimating demand equations for electricity, natural gas, propane, firewood, and coal using Mexican households' survey data from 2008 to 2014. Sprawl measures, gravity model, and central place theory are the accessibility theories supporting the accessibility indicators. The suggested energy access indicators are statistically significant and show the expected signs when applied to propane in Mexican households in 2014. The greater the household income, population size, education level of the household head, energy access, and the lower the energy price and the household size, the greater the demand for energy from 2008 to 2014. By contrast, the greater the education, the lower the demand for firewood and coal. Policy-makers in Mexico can use the suggested results to complement the energy access indicators suggested by international agencies to evaluate energy access performance and better understand the drivers of the different energy goods consumed by Mexican households.
\end{abstract}

Keywords: Energy access; Sprawl measures; Gravity model; Central place theory.

JEL Classification: D120, R220, O13

\section{INTRODUCTION}

The concept of energy access in developing countries, such as Mexico, differs from the concept in developed countries in terms of the energy goods consumed and their demand determinants. Electricity, natural gas, propane, coal, and firewood are the energy goods Mexican households consume. Indoor consumption of firewood and coal has health implications for individuals; therefore, the energy access concept in developing countries encompasses access to electricity, natural gas, and propane and a reduction on coal and firewood to heat or cook.

This paper applies sprawl measures, gravity model postulates, and central place theory to estimate energy access indicators that account for country-specific and spatial characteristics using the demand for propane in Mexican households in 2014. Estimates of demand for electricity, natural gas, propane, coal, and firewood using Mexican household data for 2008, 2010, 2012, and 2014 are also computed. 
These energy demand equations are estimated to calculate demand-price elasticity as a measure of policy effectiveness to reduce coal and firewood consumption by Mexican households. The energy demand equations also provide insight into the different energy demand drivers of electricity, natural gas, and propane that could be beneficial for policy-making.

Demand factors such as price, income, population size, household size, householder education, and energy access have been extensively discussed in the residential energy demand literature. In Mexico, except for the cross-sectional analysis in Cruz Islas (2013), there is a gap in the existing literature, between descriptive statistics, energy access indicators for developing countries, and empirical analysis applied to residential energy demand using geographical variables. Geographical data availability is potentially one of the main constraints explaining this gap. We gathered and geocoded an extensive dataset of propane gas locations across Mexico to estimate the propane demand equation.

The computation of energy access indicators informed by accessibility theory in Mexico, the application of a residential energy price index, and the empirical estimation of demand equations of Mexican households using panel data are the advancements this paper intends to make to the field. Results of the empirical analysis are used to test whether accessibility theory holds when analysing residential energy demand in Mexico and that the higher the household income, the population size, the education level of the householder, the energy access, and the lower the energy price and the household size, the greater the demand for energy in 2008-2014.

The next two sections discuss the residential energy demand theory supporting this study and the suggested energy access indicators. The methodology section describes the econometric technique used to estimate the residential demand equations. The results section discusses the estimated demand equations and energy access indicators. The final section compares the estimated energy demand elasticity with results obtained by other authors in the field, highlights opportunities for future research, and includes concluding remarks.

\section{THEORY}

Microeconomics consumer choice theory informs the residential energy demand analysis. Price, income, household size, population size, education of the householder and energy access are factors that determine residential demand for energy (Fisher \& Kaysen, 1962; Islas, 2013; Labandeira, Labeaga, \& López-Otero, 2017; O’Neill \& Chen, 2002; Poulsen \& Forrest, 1988; Salari \& Javid, 2017; Schipper, Haas, \& Sheinbaum, 1996; Taylor, 1975).

The existing literature for residential energy demand identifies energy access as the most significant factor determining the household demand for energy (Balachandra, 2011; Fisher \& Kaysen, 1962; Fitzgerald, Barnes, \& McGranahan, 1990; Pachauri, 2004). Regional science widely discusses accessibility theory in its literature. Sprawl modelling, gravity model, and central place theory provide a framework for accessibility theory. 


\subsection{Sprawl Modelling}

Sprawl modelling is a study area in the accessibility literature because individuals that live in sprawled cities have limited access to resources and community amenities (Torrens \& Alberti, 2000). Sprawl can be defined as a spread of jobs and population throughout a city in low, dense living and working areas (Glaeser \& Khan, 2004).

Glaeser and Khan (2004) argue that the more disperse and decentralize the population, the greater the sprawl; therefore, the authors use Equation (1) as a sprawl measure.

$$
\log (\text { density })=a+b(\text { distance from CBD })+e .
$$

Density refers to the individuals per mile in a zip code. The distance variable refers to the distance from the central business district (CBD) to the zip code.

The sprawl measure in Equation (1) can be applied to measure residential energy access. The density variable denotes the number of households per mile. The distance variable is the distance from the household to the closest propane station.

\subsection{Gravity Model}

The gravity model can be applied to social interactions and to estimate the size and direction of spatial flows or trips (Head, 2003). Torrens and Alberti (2000) categorize the gravity model as a spatial interaction model to measure sprawl and accessibility as in Equation (2).

$$
F_{i j}=G \frac{M_{i}^{\alpha} M_{j}^{\beta}}{D_{i j}^{\theta}}
$$

where $F$ denotes the trip or accessibility between an origin and a destination; $M_{i}$ refers to "the capacity of an origin to generate trips", $M_{j}-$ "the ability of activities at a destination to attract those trips", and $D$ is "the distance over which the trips must be traversed and some weighting mechanism, theta, that discourages trips over long distances" (Torrens \& Alberti, 2000, 30).

In areas of some developing countries, such as in Mexico, propane is delivered by trucks. Access to propane of those households depends on the trips the delivery truck makes. Propane retailers make deliveries to those places where individuals can afford to purchase propane. It takes longer for trucks to make trips in areas with lower income (Masera, Saatkamp \& Kammen, 2000).

\subsection{Central Place Theory}

The Central Place Theory (CPT) and the monopolistic competition model provide an approach to measure accessibility. The monopolistic competition model can be applied to different contexts; Nicholson and Snyder (2011) explain its applications to quality. Becker (2009) applies the model to education and the 
"quality" of children. The market area concept is an application of the monopolistic competition model to the CPT (O'Sullivan, 2005).

Output, population density, and demand per capita determine the market areas of market-oriented firms. Equation (3) defines the market area concept applied to the demand for propane demand.

$$
M=\frac{q}{d e}
$$

where $M$ is the market area of a propane station in kilometres, $q$ is its target output, $d$ denotes the demand of propane per household, and $e$ is the population density (households per square $\mathrm{km}$ ). The market area of the propane station $(M)$ is the territory required to sell its targeted quantity $(q)$.

An increase in the demand per capita decreases the market area because the volume of units sold per mile goes up. Therefore, the propane station requires a smaller market area. An increase in population density decreases the market area because the volume of sales increases, so the propane retailer requires less territory to exploit economies of scale (O'Sullivan, 2005).

\subsection{Demographic and Social Factors of Residential Energy Demand}

Population size is considered a residential energy demand factor, and it can be used to designate areas into rural or urban. There is a debate in the literature on whether coal and firewood are substitutive goods of propane, natural gas, and electricity in urban and rural households. Results vary from developing and developed countries.

In some developing countries such as Indonesia, India, Guatemala, and Mexico, households in rural and in urban areas combine traditional energy with modern energy (Barnes, Krutilla \& Hyde 2004; Barnes \& Qian 1992; Hosier \& Dowd, 1989; Fitzgerald, Barnes \& McGranahan, 1990; Heltberg, 2005; Pachauri, 2004; Pachauri, Rao, Nagai \& Riahi, 2012; Reddy, 2015). Studies for developed countries mainly focus on residential energy demand in urban areas (Eakins, 2013; Lakshmanan \& Anderson, 1980; Mount, Chapman \& Tyrrell, 1973; Salari \& Javid, 2016; Salari \& Javid, 2017; Schuler, Weber \& Fahl, 2017; Schulte \& Heindl, 2017). Household size influences residential energy demand by affecting the per capita energy demand. The greater the household, the lower the per capita energy demand. The negative relationship between household size and per capita energy demand can be attributed to income, age of the household members, the composition of the household, and economies of scale (O'Neill \& Chen, 2002).

Energy consumption per capita decreases as family member increases because the income per capita declines. Larger households generally have many children. Children consume less transportation energy than adults. The greater number of children at the household, the lower the per capita energy consumption (O'Neill \& Chen, 2002). One-person households consume more energy per capita than households with more family members (Islas, 2013).

The household size affects the household capabilities to exploit scale economies. Economies of scale are defined as the declining portion of the long-run 
average cost curves when output increases. As household size increases, the average long-run cost of maintaining a given standard of living declines, all else being equal due to economies of scale (Bosch-Domènech, 1991; Deaton \& Paxson, 1998; O'Neill \& Chen, 2002).

The household can exploit scale economies as the family members increase. The per capita cost of maintaining a given standard of living declines as household size increases because goods such as space, home furnishings, transportation services, and energy are shared between more household members (BoschDomènech, 1991; Deaton \& Paxson, 1998; Islas, 2013; O’Neill \& Chen, 2002).

Apart from the household size and the population size, other demographic factors affect the energy consumption patterns, hence, the residential energy demand. A higher divorce rate, aging, later ages at marriage, propensities to live alone are factors that influence the energy consumption patterns especially in developing countries (O’Neill \& Chen, 2002). Fisher and Kaysen (1962) argue that the number of marriages affects residential energy demand. Cruz (2013) considers age and the number of economic dependents in households to be significant factors affecting the residential energy demand.

O'Neill and Chen (2002) state that such detailed factors affect only the longrun residential energy demand because it takes time for countries to experience these compositional changes to significantly affect energy demand. Apart from demographic and economic factors, householder education influences the residential energy demand (Balachandra, 2011; Fisher \& Kaysen, 1962; Fitzgerald, Barnes, \& McGranahan, 1990).

The education of the householder is a social factor that influences residential energy demand. Education measured as years of schooling affects the income elasticity of a good. The opportunity cost of an individual explains the role education plays in determining whether a good is an inferior good or a normal good. Becker (1992) explains children to be an inferior good as women get more education and participate more in the labour force.

The more educated women and their greater participation in the labour force will lead to higher opportunity cost of bearing children (Becker, 2009). When years of schooling of women and their participation in the labour force rise, children become an inferior good. As the income of a woman goes up, children become more expensive; hence, women demand fewer children as their income raises.

Space heating and cooking using firewood and coal take longer than using natural gas, propane, or electricity. When the householder collects firewood or uses firewood and coal, the opportunity cost of using those fuels increase as with additional education. Education affects the income elasticity of energy. If coal and firewood are inferior goods, then theory such as Becker (2009) and empirical studies, as in Eakins (2013), will support the results.

\section{POLICY}

The United Nations (UN), the World Bank, and the International Energy Agency (IEA) are institutions that provide their member countries with energy policy recommendations. These agencies base their policy recommendations on 
energy access and energy efficiency indicators. Developing countries give for granted their achievements in energy access as measured by these indicators to conduct domestic energy policy. For example, Mexico ranks as a country with complete energy access, and its energy policy agenda focuses on achieving energy efficiency and on reducing natural gas prices, but it overlooks energy access.

The Sustainable Development Goals (SDG) of the UN provide policy recommendations to its member countries through 17 goals and 169 targets. The SDG 7 recommends ensuring access to affordable, reliable, sustainable, and modern energy for all by 2030 (UN, n. d.). Other international agencies such as the World Bank follow up the SDG 7 and conduct energy access and energy efficiency indicators.

The World Bank computes energy access indicators through its Regulatory Indicators for Sustainable Energy (RISE) report. The RISE report evaluates the policy and regulations of its member countries regarding energy access, energy efficiency, and renewable energy (Banerjee et al., 2017).

Nordhaus (1973) argues that the System Dynamic (SD) models, such as the World Dynamics of the Club of Rome, are measurements without data because they do not conduct an empirical analysis. Therefore, the author considers SD models no better than mental maps. The Nordhaus' critique to the World Dynamics applies to the RISE report because it does not include an empirical analysis or a theory to support its indicators.

The RISE indicators rank Mexico in the highest ranking of energy access because it has a regulatory framework as the other OECD countries. WB energy access has empirical and conceptual limitations. The WB energy access indicators focus on evaluating policies and regulation but do not include empirical data to account for country-specific factors. They consider access to electricity and energy access indifferently and overlook the reduction of coal and firewood household consumption.

The IEA and the Mexican Ministry of Energy (SENER) developed a statistical framework to compute residential energy-related indicators and provided Mexico with policy recommendations. The IEA indicators and policy recommendations focused on energy efficiency. Similarly to the WB indicators, the IEA overlooked energy access.

Mexico implemented an Energy Reform (ER) in 2015. The ER intends to improve technology in the oil extraction process through attracting foreign investment, and it has a major goal to decrease the oil and natural gas prices to benefit Mexican households. Energy access and other country-specific factors of demand energy are omitted in the ER as in the indicators of the international agencies.

Accessibility theory can be applied to household data to estimate energy access indicators that account for country-specific factors. Market areas, as explained in O'Sullivan (2005), trip spatial patterns as in Torrens and Alberti (2000), and sprawl measures as in Glaeser and Khan (2005) can be used to compute energy access indicators. 


\section{METHODOLOGY}

This section specifies the equations to estimate residential demand for electricity, natural gas, propane, coal, and firewood, and two sets of equations to determine whether accessibility theory holds when applied to demand for propane in Mexican households.

The household demand for energy sources is a function of economic, demographic, and social factors as in Equation (4). Price, income, population size, household size, education of the householder, and energy access are the variables we use to account for these factors.

$$
Q d=f(\text { economic factors, demographic factors, social factors) }
$$

Equation (5) specifies the demand for electricity (I), natural gas (II), propane (III), coal (IV), and firewood (V). Equation (5) accounts for country-specific demand factors, and it can be used to estimate the demand for energy goods in developing countries if data are available. This paper uses Mexican household data from 2008 to 2014 to estimate the demand equations.

$$
\begin{aligned}
\ln Q_{i, t}^{j} & =\beta_{0}+\beta_{1} \ln P_{t}^{j}+\beta_{2} \ln P_{t}^{r o e}+\beta_{3} \ln Y_{i, t}+\beta_{4} R D_{i, t}+\beta_{5} \ln H H S_{i, t}^{j} \\
& +\beta_{6} \ln E D U_{i, t}^{j}+\beta_{7} E A D_{i, t}^{j}+u_{i, t}
\end{aligned}
$$

where $Q$ is the household expenditure on energy good $j, P$ is the price for energy good $j, P_{t}^{\text {roe }}$ is the weighted average of the price of the rest of the energy sources, $Y$ is the household's income, $R D$ is a dummy variable. $R D$ is 1 if the household is in a rural area. HHS is the household size in number of family members, $E D U$ is the education of the householder in years of schooling and $E A D$ is an energy access dummy variable which takes the value of 1 if the household has access to electricity.

The superscript $j$ denotes electricity, natural gas, propane, coal or firewood. The subscript $i$ and $t$ denote household and time period, respectively. Except for $R D$ and $E A D$, all the variables are expressed in natural logs, so the results can be interpreted as elasticity.

The residential energy literature has discussed all the factors in Equation (5). Results of demand estimates in developing countries and in developed countries vary. Apart from the country-specific demand factors, Labandeira et al. (2017) argue that the specification of the demand model, the type of data, the technique used to estimate the demand equation, and the analysis period are the sources of the differences in the demand estimates for different countries.

\subsection{Demand-Price Elasticity}

Demand-price elasticity is the sensibility of a good to change in its price. Demand-price elasticity is computed as the percent variation of quantity demanded when its price changes. Let us assume the price of good $x$ decreases by $1 \%$. If the quantity demanded of $x$ increases by more than $1 \%$, the good is price elastic. A 
good is price inelastic if its quantity demanded increases by less than $1 \%$ when its price decreases by $1 \%$.

In developing countries such as Indonesia, natural gas and kerosene are price elastic (Fitzgerald et al.,1990). In developed countries such as the United States, the household demand for electricity is price inelastic but lower than one (Fisher \& Kaysen, 1962). In Germany, residential demand for energy goods is price inelastic, but in some cases, they are greater than one (Sancho-Tomas, Sumner, \& Robinson, 2016). The authors attributed these differences to the different time periods being employed while estimating their model.

In Mexico, electricity, natural gas, and firewood are expected to be price elastic as in other developing countries. The expected sign of the price elasticity for energy goods is negative and greater than one (in absolute terms).

\subsection{Cross-Price Elasticity}

Demand-cross-price elasticity is the sensibility of the demand of good $x$ to change in the price of good $y$. Let us assume the price of good $y$ increases by $1 \%$. If the demand for good $x$ decreases, good $x$ and good $y$ are complementary goods. If the demand for good $x$ increases when the price of good y increases, good $x$ and good $y$ are substitutive goods.

Natural gas and electricity are substitutive goods in the U.S. (Salary \& Javid, 2017). In Indonesia, fuelwood, kerosene, and natural gas are substitutive goods (Fitzgerald et al., 1990). In Mexico, firewood is a substitutive good of propane (Masera et al., 2000), but propane is not a substitutive good of firewood because the access to propane is limited in some rural households (Masera et al., 2000). In rural households and poor urban households of Guatemala, firewood and propane are complementary goods (Heltberg, 2005). We expect to find that the energy goods in Mexican households are complementary goods, as in Masera et al. (2000).

\subsection{Income Elasticity}

Income elasticity refers to the sensibility of the quantity demanded of a good when income changes. Let us assume the income of a household increases by $1 \%$. Good $x$ is considered to be income elastic or a normal good if its demand increases. If the demand for a normal good increases by more than $1 \%$, the good is a luxury good. If the demand for a normal good increases by less than $1 \%$, the good is a necessity good. If the demand of good $x$ decreases when income goes up by $1 \%, x$ is an inferior good. Coal and firewood are expected to be inferior goods and electricity, natural gas, and propane - normal goods.

\subsection{Population and Household Size}

Population size can be used to designate an area as rural or urban (U.S. Census Bureau, 2010). The level of urbanization is a factor affecting the residential energy demand (Fisher \& Kaysen, 1962; Heltberg, 2005; Salari \& Javid, 2017). Equation (5) uses $R D$ to proxy level of urbanization. $R D$ is a dummy variable that 
takes the value of 1 if a household is in an area with population less than $2500 . R D$ is expected to be positive in the demand equation for electricity, natural gas, and propane and negative for coal and firewood as in Fisher and Kaysen (1962).

Household size defined as the number of family members in a household is a demographic determinant of the residential energy demand. If the number of family members in a household increases, their per capita demand decreases due to economies of scale. As the number of family members increases, the residential demand is expected to decrease as a consequence of scale economies, assuming constant return to scale and not overcrowding as in O'Neill and Chen (2000).

\subsection{Education}

Education in years of schooling is a determinant of the demand for energy goods (Salari \& Javid, 2017). Heating and cooking take longer when using coal and firewood as the householder gets more years of schooling; the opportunity cost of using coal and firewood increases. When the opportunity cost of using coal and firewood goes up, their demand goes down. Electricity, natural gas, and propane are faster energies to cook or heat. As the years of schooling go up, the demand for electricity, propane, and natural gas go up. Therefore, education is expected to be positive for electricity, natural gas, and propane, and negative for firewood and coal in Mexico.

\subsection{Energy Access}

Energy access is a determinant of residential energy demand (Fisher \& Kaysen, 1962; Fitzgerald, Barnes, \& McGranahan, 1990; Masera et al., 2000). The first set of equations, proxy energy access with a dummy variable denoting 1 if the household is connected to the grid, zero otherwise as in Fisher and Kaysen (1962). Besides Fitzgerald, Barnes, \& McGranahan, 1990, empirical studies and policy briefings consider access to electricity and energy access indifferently. As a consequence, results in energy access terms can be overstated because households consume other energy goods.

The second set of equations is specified to estimate the residential demand for propane in 2014 to determine whether accessibility theory holds using Mexican household data. Equation (6-I) uses access to propane as an energy access indicator.

$$
\begin{gathered}
\ln Q_{i, 2014}^{L P G}=\beta_{0}+\beta_{1} \ln P_{2014}^{L P G}+\beta_{2} \ln P_{2014}^{r o e}+\beta_{3} \ln Y_{i, 2014}+\beta_{4} R D_{i, 2014} \\
+\beta_{5} \ln H H S_{i, 2014}^{L P G}+\beta_{6} \ln E D U_{i, 2014}^{L P G}+\beta_{7} L P G A D_{i, 2014}^{L P G}+u_{i} .
\end{gathered}
$$

All of the variables in Equation (6-I) make reference to those variables in Equation (5) except for the energy access variable. Households need a tank to store propane. $L P G A D$ is a dummy variable that takes the value of 1 when the household has at least one propane tank.

Equation (6-II) specifies the residential demand for propane in 2014 using the sprawl measure in Glaeser and Khan (2004). 


$$
\begin{aligned}
\ln Q_{i, 2014}^{L P G}=\beta_{0} & +\beta_{1} \ln P_{2014}^{L P G}+\beta_{2} \ln P_{2014}^{r o e}+\beta_{3} \ln Y_{i, 2014}+\beta_{4} d i s t_{i-L P G S, 2014} \\
& +\beta_{5} \ln H H S_{i, 2014}^{L P G}+\beta_{6} \ln E D U_{i, 2014}^{L P G}+u_{i} .
\end{aligned}
$$

The energy access indicator in Equation (6-II) dist $t_{i-L P G S, 2014}$ refers to the distance from the closest propane station to the census tract of household $i$ as an energy access indicator. The coefficient $\beta_{4}$ is expected to be negative. The farther the household location from the propane station, the lower the energy access and the lower its demand for propane.

Propane is distributed to households by delivery trucks in Mexico and other developing countries such as Belize, Guatemala, El Salvador, Honduras, Nicaragua, Costa Rica, Peru, and Bangladesh. Existing literature attributes trips from the propane station to the household as a determinant for energy access (Masera et al., 2000).

The gravity model can be used to measure the accessibility in terms of trips between an origin and a destination (Torrens \& Albertani, 2000; Torrens, 2000). Equation (6-III) specifies the demand for propane using the gravity model to measure energy access.

$$
\begin{gathered}
\ln Q_{i, 2014}^{L P G}=\beta_{0}+\beta_{1} \ln P_{2014}^{L P G}+\beta_{2} \ln P_{2014}^{r o e}+\beta_{3} \ln Y_{i, 2014} \\
+\beta_{4} \ln C a p_{L P G S, 2014}+\beta_{5} \text { dist }_{i-L P G S, 2014} \\
+\beta_{6} \ln H H S_{i, 2014}^{L P G}+\beta_{7} \ln E D U_{i, 2014}^{L P G}+u_{i} .
\end{gathered}
$$

The household $i$ is the destination and its closest propane station is the origin (LPGS). Cap denotes the maximum production capacity of propane. dist $t_{-L P G S, 2014}$ is the Euclidean distance between the census tract of the household $i$ and the propane station. The household income $Y_{i, 2014}$ is interpreted as the ability of the destination to attract trips of the propane delivery truck.

The higher the household income, the more attracted the propane truck to make trips; therefore, $\beta_{3}$ is expected to be positive. The greater the production capacity of the propane station, the lower its incentive to make trips because the propane station expects customers to travel to purchase propane; therefore, $\beta_{4}$ is expected to be negative. The distance between the household $i$ and propane station discourages long-distance trips; hence, $\beta_{5}$ is expected to be negative. The summation of $\beta_{3}, \beta_{4}$, and $\beta_{5}$ is expected to be positive; the greater the energy access, the greater the residential demand for propane.

Equation (6-IVa) specifies the propane demand equation when using the market area concept as of the propane station to measure energy access

$$
\begin{gathered}
\ln Q_{i, 2014}^{L P G}=\beta_{0}+\beta_{1} \ln P_{2014}^{L P G}+\beta_{2} \ln P_{i, 2014}^{r o e}+\beta_{3} \ln Y_{i, 2014}+\beta_{4} \ln \operatorname{Cap}_{L P G S, 2014} \\
+\beta_{5} \ln H H U_{A G E B, 2014}+\beta_{6} \ln A R E A_{A G E B, 2014} \\
+\beta_{7} \ln H H S_{i, 2014}+\beta_{8} \ln E D U_{i, t}^{j}+u_{i} .
\end{gathered}
$$

Cap is the maximum capacity of the propane station. The greater the production capacity of the propane station, the lower its incentive to deliver propane to the household; therefore, the propane access decreases. The lower the propane energy 
access, the lower the household demand for propane. Therefore, $\beta_{4}$ is expected to be negative.

$H H U$ is the number of households per census tract. $\beta_{5}$ is expected to be positive, the greater the number of households per census tract, the greater the demand for propane. AREA is the area of the census tract of the household. The greater the census tract, the lower the accessibility and the lower the propane demand; therefore, $\beta_{6}$ is expected to be negative. Equation (6-IVb) uses population instead of housing units in Equation (6-IVa).

$$
\begin{gathered}
\ln Q_{i, 2014}^{L P G}=\beta_{0}+\beta_{1} \ln P_{2014}^{L P G}+\beta_{2} \ln P_{2014}^{r o e}+\beta_{3} \ln Y_{i, 2014}+\beta_{4} \ln \operatorname{Cap}_{L P G S, 2014} \\
+\beta_{5} \ln P_{0 p_{A G E B, 2014}}+\beta_{6} \ln A R E A_{A G E B, 2014} \\
+\beta_{7} \ln H H S_{i, 2014}+\beta_{8} \ln E D U_{i, t}^{j}+u_{i} .
\end{gathered}
$$

\subsection{Estimation Methods and Data}

The residential energy demand equations are estimated with the help of fixed effects panel methods using data from the Household Expenditures and Income Survey (HEIS). The HEIS is a national survey the Ministry of Statistics of Mexico (INEGI) conducts on a bi-annual basis. Except for the energy prices, the population by census tract, and the spatial variables, all the variables are obtained from the HEIS from 2008 to 2014.

The demand equations for propane are estimated by Ordinary Least Squares (OLS) methods. The population and household units by census tract, the census tract area, and its distance to the propane stations are obtained from INEGI and the Regulatory Energy Commission of Mexico. Data availability allows us to estimate the demand for propane and to compute energy access indicators for 2014.

The HEIS surveyed 35 146, 30 169, 10062 and, 21427 households for 2008, 2010, 2012, and 2014, respectively. The survey provides information on household expenditure on electricity, natural gas, propane, coal, and firewood. It provides data on income, access to electricity and propane, number of family members in the households, years of schooling of the householder, and whether the household is in a rural or an urban area.

Figure 1 shows the household consumption of different energy goods from 2008 to 2014 . Electricity shares $50 \%$ of the total residential energy consumption. Propane ranks second, followed by natural gas. Coal and firewood are the lowest energy goods that Mexican households consume. 


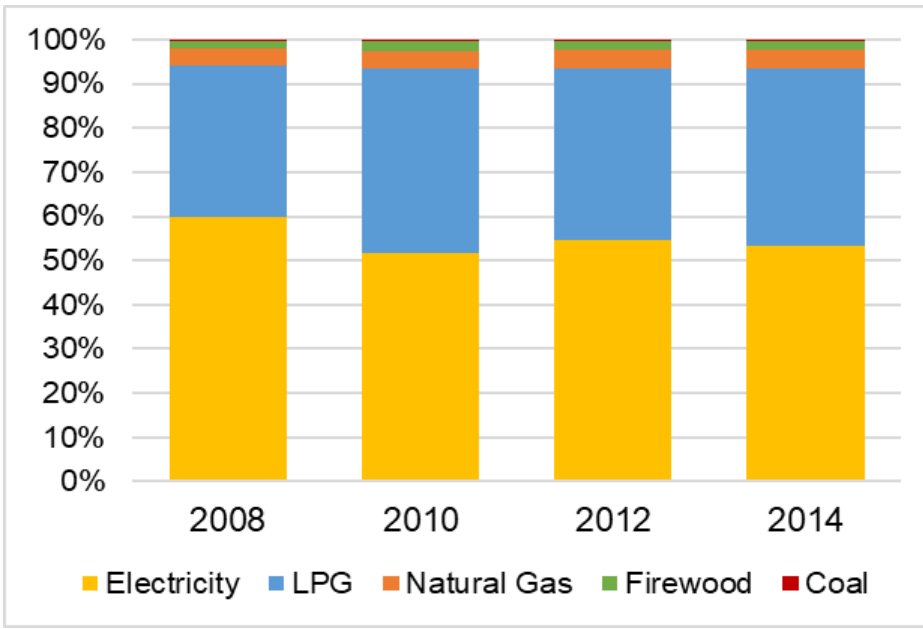

Fig. 1. Household energy consumption by energy goods, 2008-2014 (INEGI, 2015a).

The National Energy Balance (SENER, 2016) publishes residential prices for electricity, natural gas, and propane in Mexico. Figure 2 shows the real price of electricity from 2005 to 2015. The price of electricity increased from 2005 to 2011. In 2012 and 2013, electricity prices decreased. In 2014 and 2015, the electricity price increased.

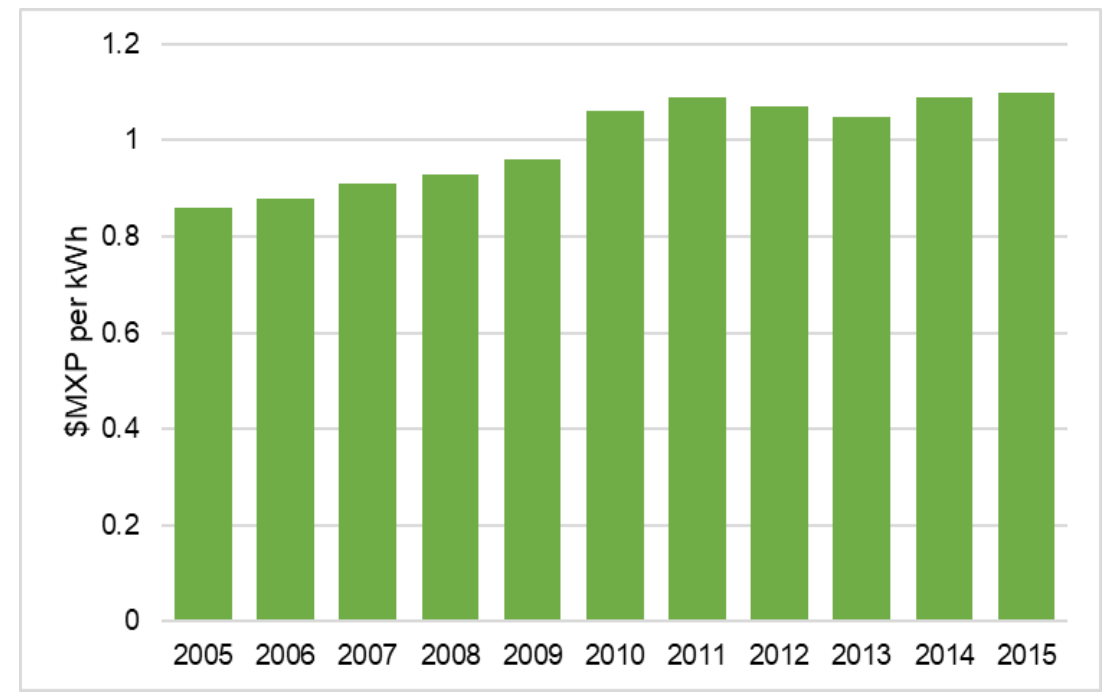

Fig. 2. Electricity price in 2015 \$MXP, 2005-2015

(SENER, 2016).

Figure 3 shows the price for natural gas from 2005 to 2015 in 2015 \$MXP. Natural gas prices decreased in 2005 and 2006. It then increased from 2006 to 2010. The price for natural gas decreased from 2011 to 2013, and it peaked in 2014. 


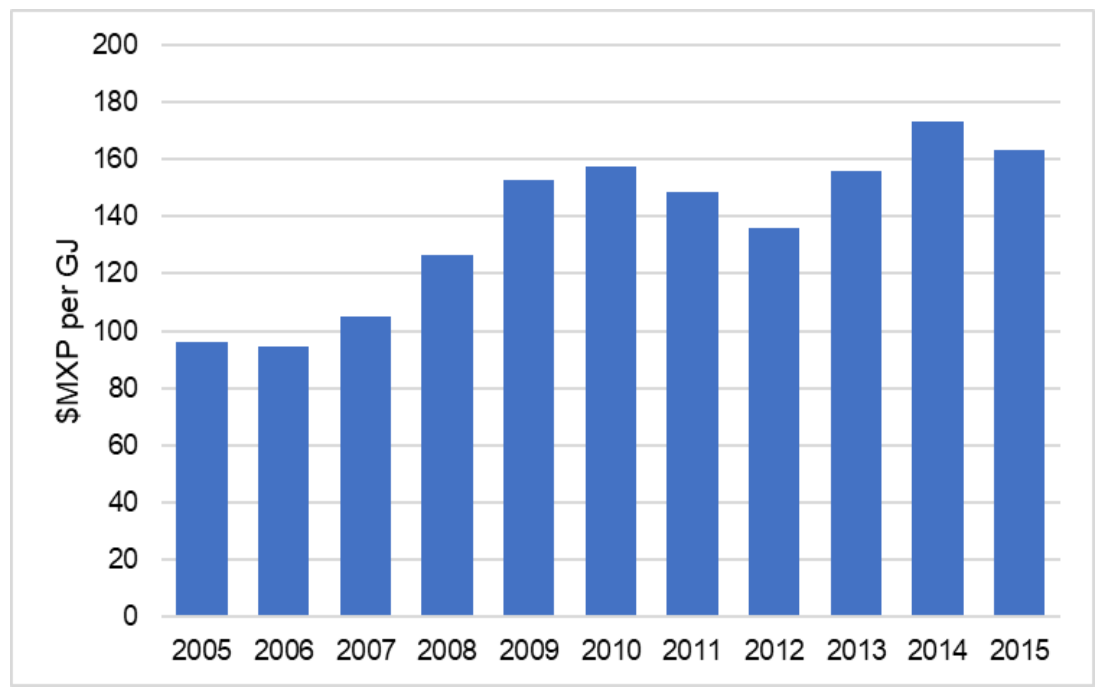

Fig. 3. Natural gas price in 2015 \$MXP, 2005-2015

(SENER, 2016).

Figure 4 shows the price for propane from 2005 to 2015 in 2015 \$MXP. The propane has shown an increasing trend over the analysis timeframe because of liberalization of a subsidy to propane.

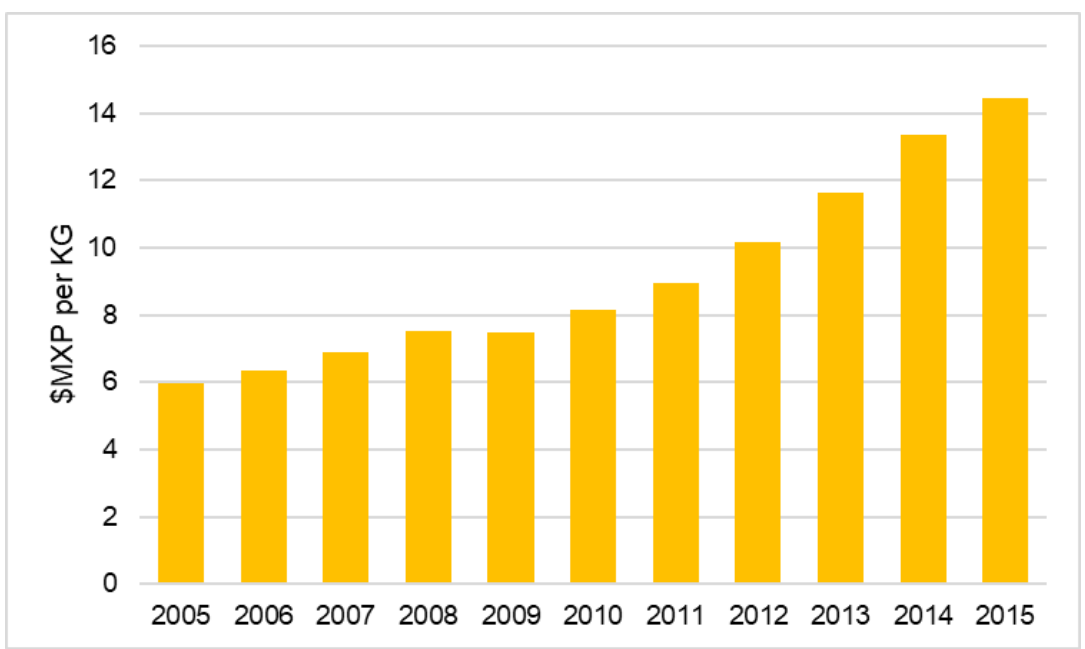

Fig. 4. Propane price in 2015 \$MXP, 2005-2015 (SENER, 2016).

Figure 5 presents the price for coal from 2005 to 2015 in 2015 \$MXP. The price for coal increased from 2005 to 2008. Its price peaked in 2009. In 2010, it decreased, and in 2011, it increased. Coal price dropped in 2012, and it showed an increasing trend from 2012 to 2015 . We used the import price of wood fuel reported by FAO as a proxy for firewood prices. 


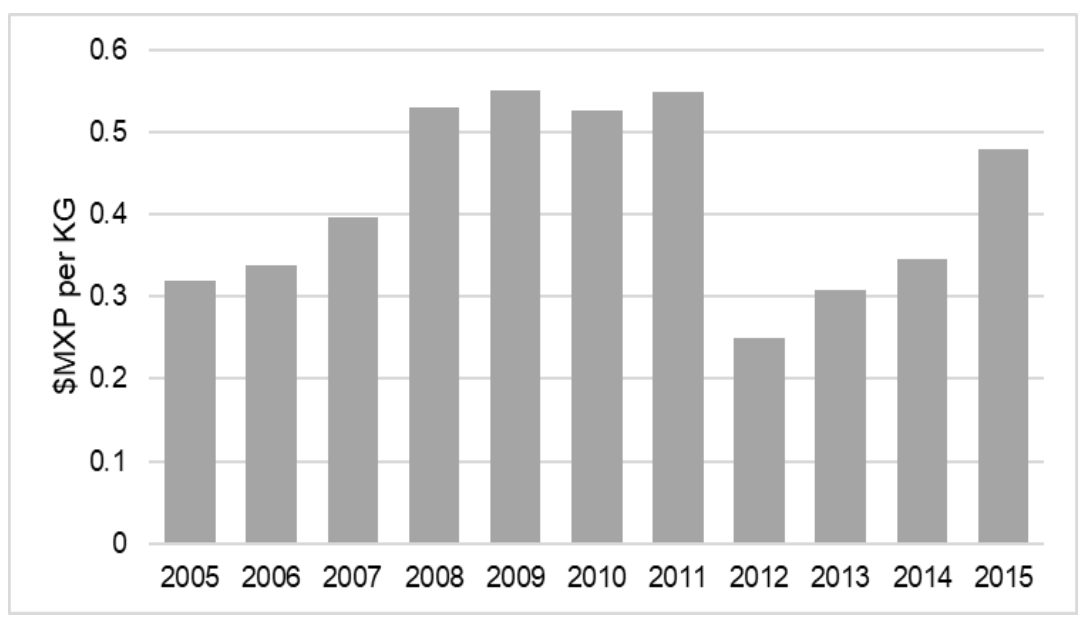

Fig. 5. Coal price in 2015 \$MXP, 2005-2015

(Mexican Geological Service, 2017).

The $P_{t}^{\text {roe }}$ variable in the demand equations refers to a Residential Energy Price Index (REPI). The REPI is a weighted price for energy goods households consume. To compute the REPI, the unit prices of the different energy goods were standardized to \$MXP/MJ using the energy equivalence in Table 1.

Table 1. Conversion Factors for Different Energy Goods

\begin{tabular}{|c|c|c|}
\hline Energy Good & Conversion Factor & Source \\
\hline Electricity & $1 \mathrm{kWh}=3.6 \mathrm{MJ}$ & SENER $(2016)$ \\
\hline Natural Gas & $1 \mathrm{~kg}=0.045 \mathrm{MJ}$ & FAO $(1987)$ \\
\hline Propane & $1 \mathrm{~kg}=49 \mathrm{MJ}$ & Hahn $(2019)$ \\
\hline Coal & $1 \mathrm{~kg}=0.03 \mathrm{MJ}$ & FAO $(1987)$ \\
\hline Firewood & $1 \mathrm{~kg}=0.019 \mathrm{MJ}$ & FAO $(1987)$ \\
\hline
\end{tabular}

The share of energy goods household consume are the weights used to compute the REPI uses. Table 2 shows the weights applied to the energy goods.

Table 2. Calculated Weights for Energy Goods

\begin{tabular}{|c|c|c|c|c|}
\hline Weights & $\mathbf{2 0 0 8}$ & $\mathbf{2 0 1 0}$ & $\mathbf{2 0 1 2}$ & $\mathbf{2 0 1 4}$ \\
\hline Electricity & 0.599908 & 0.517822 & 0.545126 & 0.532618 \\
\hline Propane & 0.341213 & 0.41529 & 0.388059 & 0.401549 \\
\hline Natural Gas & 0.040515 & 0.039287 & 0.043178 & 0.043529 \\
\hline Firewood & 0.015409 & 0.022814 & 0.018938 & 0.018826 \\
\hline Coal & 0.002955 & 0.004788 & 0.004699 & 0.003478 \\
\hline
\end{tabular}

The REPI follows the methodology of other weighted average used as indices by some agencies. For instance, the weighted average feeder cattle price, the 
weighted average poultry prices, the food price index, and the agriculture price index are computed by the Missouri Department of Agriculture (2017), the Georgia Department of Agriculture (n. d.), the FAO (n. d.), and the World Bank (2017), respectively.

The REPI-I is the weighted average of natural gas, propane, coal, and firewood prices. REPI-II averages the price of electricity, propane, coal, and firewood. REPIIII is the weighted average price of electricity, natural gas, coal, and firewood. REPI-IV averages electricity, natural gas, propane, and firewood with their corresponding weights. REPI-V is the weighted average price of electricity, natural gas, propane, and firewood. Figure 6 plots the REIs from 2008 to 2014.

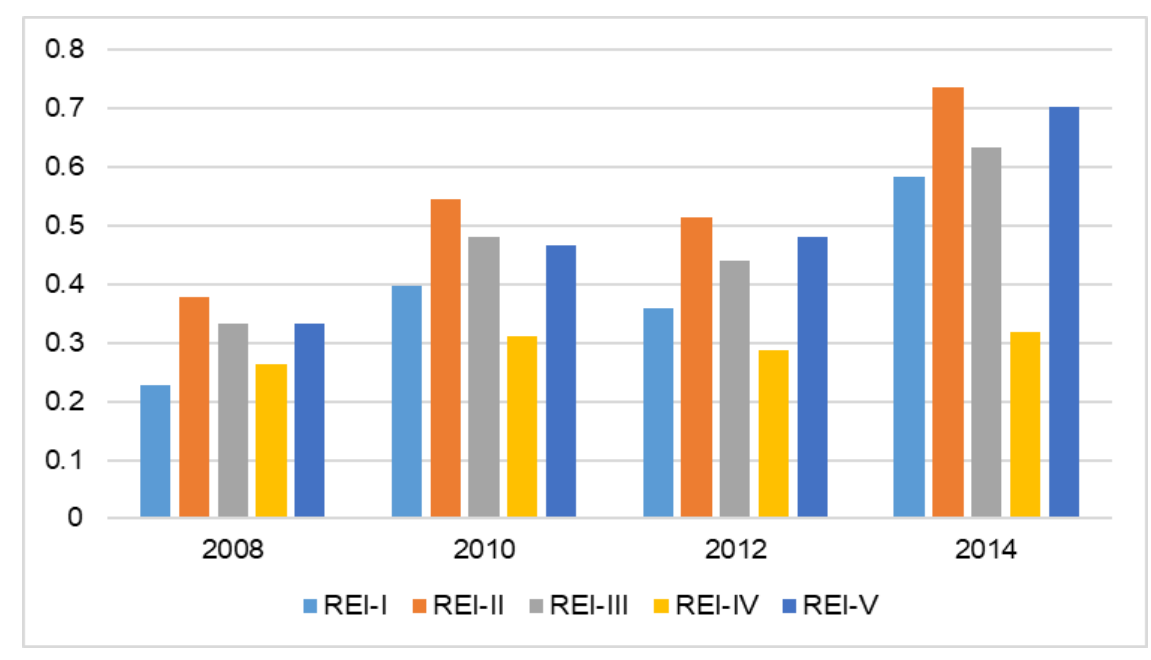

Fig. 6. Residential energy price indices, 2008-2014 (FAO, n. d.; INEGI 2015a, Mexican Geological Service, 2017; SENER, 2016).

The household average quarterly income was \$33 519 MXP, and the median household quarterly income was \$20 577 MXP in 2008. In 2010, the average income of surveyed households decreased, but the median income increased when compared to 2008. In 2012, the average household earned \$32 361. In 2014, average and median income were \$33 201 and \$21 804, respectively. Table 3 provides information on the number of surveyed households that provided income information on the average income and the median income.

Table 3. Household Income in \$MXP, 2008-2014

\begin{tabular}{|c|c|c|c|c|}
\hline & $\mathbf{2 0 0 8}$ & $\mathbf{2 0 1 0}$ & $\mathbf{2 0 1 2}$ & $\mathbf{2 0 1 4}$ \\
\hline Average income & 33519.47 & 31974.74 & 32361.70 & 33201.97 \\
\hline Median income & 20576.57 & 21006.98 & 20739.12 & 21804.43 \\
\hline
\end{tabular}

The 2008 HEIS provided quarterly income information for 28866 households. Six thousand six hundred four of the surveyed households that provided income information were in rural areas, and 22262 households were in 
urban areas. Table 4 shows the number of surveyed housing units in rural and urban areas from 2008 to 2014.

Table 4. Rural and Urban Households, 2008-2014

\begin{tabular}{|c|c|c|c|c|}
\hline & $\mathbf{2 0 0 8}$ & $\mathbf{2 0 1 0}$ & $\mathbf{2 0 1 2}$ & $\mathbf{2 0 1 4}$ \\
\hline HHs in rural areas & 6604 & 6019 & 3235 & 5147 \\
\hline HHs in urban areas & 22262 & 21010 & 5610 & 13958 \\
\hline Surveyed HH with income data & 28866 & 27029 & 8845 & 19105 \\
\hline
\end{tabular}

The categories of education of the householder range from no education to graduate school. The average householder lies in the incomplete advanced middle school category from 2008 to 2014. Table 5 shows the number of householders that lie in each category every year.

Table 5. Education Level of the Householder, 2008-2014

\begin{tabular}{|l|c|c|c|c|}
\hline \multicolumn{1}{|c|}{ Education Level } & $\mathbf{2 0 0 8}$ & $\mathbf{2 0 1 0}$ & $\mathbf{2 0 1 2}$ & $\mathbf{2 0 1 4}$ \\
\hline 1. No formal education & 2824 & 2665 & 958 & 1520 \\
\hline 2. Elementary School & 60 & 59 & 1922 & 22 \\
\hline 3. Incomplete Middle School & 6160 & 5546 & 1587 & 3475 \\
\hline 4. Middle School completed & 5339 & 4959 & 323 & 3249 \\
\hline 5. Incomplete Advanced Middle School & 1159 & 1029 & 1966 & 689 \\
\hline 6. Advanced Middle School completed & 6017 & 5770 & 254 & 4612 \\
\hline 7. Incomplete High School & 906 & 808 & 772 & 702 \\
\hline 8. High School complete & 2398 & 2357 & 225 & 2085 \\
\hline 9. Incomplete undergraduate & 754 & 672 & 717 & 533 \\
\hline 10. Bachelor's Degree & 2757 & 2701 & 137 & 1915 \\
\hline 11. Graduate Degree & 493 & 520 & 958 & 322 \\
\hline
\end{tabular}

In Mexico, 98 percent of the surveyed households had access to electricity from 2008 to 2014. Table 6 shows the number of households with electricity and the total number of housing units in the analysed time period.

Table 6. Electricity Access, 2008-2014

\begin{tabular}{|l|c|c|c|c|}
\hline & $\mathbf{2 0 0 8}$ & $\mathbf{2 0 1 0}$ & $\mathbf{2 0 1 2}$ & $\mathbf{2 0 1 4}$ \\
\hline Access to electricity & 28108 & 26444 & 8597 & 18818 \\
\hline Surveyed HH with income data & 28866 & 27029 & 8845 & 19105 \\
\hline
\end{tabular}

The number of housing units that are connected to the grid aligns with data provided by other Mexican government bodies (SENER, 2016). International agencies take statistical information from official documents for each country. 
Therefore, reports such as RISE aligns with HEIS data (World Bank, 2017). Even when the percentage of housing units connected to the grid is high, it does not guarantee complete access to energy because electricity is not the only energy good households consume.

Propane ranks second in the consumption of energy by Mexican households. The international agencies compute the existing energy access indicators based on electricity access and exclude propane from their analysis. We use different approaches to measure access to propane to verify whether accessibility theory holds using household data: a direct measure, a sprawl accessibility measure, a gravity model measure, and a market area measure.

The direct measure consists of identifying whether the household has a propane storage tank as an energy access indicator. The sprawl energy access approach uses the distance from the household census tract to the closest propane station. The gravity model approach uses the maximum production capacity of the closest propane station to the household census tract and its distance. The market area approach uses distance, maximum capacity of the closest propane station to the census tract, the number of housing units per census tract, and the census tract area to measure energy access. Table 7 shows the number of households that have at least one tank to store propane.

Table 7. Propane Access, 2008-2014

\begin{tabular}{|l|c|c|c|c|}
\hline & $\mathbf{2 0 0 8}$ & $\mathbf{2 0 1 0}$ & $\mathbf{2 0 1 2}$ & $\mathbf{2 0 1 4}$ \\
\hline Access to propane & 14665 & 13210 & 3837 & 9411 \\
\hline Surveyed HH with income data & 28866 & 27029 & 8845 & 19105 \\
\hline
\end{tabular}

We retrieved census tract geographical data from INEGI and computed their areas with ArcGIS. We gathered the locations of the propane distributional stations in Mexico from the Energy Regulatory Commission. Then, we computed the distance from the census tract to the closest propane station using the proximity tool of ArcGIS 10.5.2.

\section{RESULTS}

The energy access concept encompasses the access of households to electricity, natural gas, and propane and the extent of their reliance on coal and firewood (Balachandra, 2011; Jones, 2010; Pachauri et al., 2012). Residential energy demand estimates allow controlling for country-specific demand determinants and computing elasticity. Demand-price elasticity and cross-price elasticity of energy goods can be used to complement energy access indicators and to reconsider energy policy, such as subsidies to energy goods.

Energy access indicators in Mexico overlook the reduction of household reliance on coal and firewood and focus on access to electricity. Fitzgerald et al. (1990) compute cross-price elasticity to evaluate the effect a kerosene subsidy had on coal consumption in Indonesia. Their results suggest that the kerosene subsidy contributed to reducing the consumption of coal; therefore, energy access 
improved. Demand equations of different energy goods and price elasticity in Mexico are used to evaluate the effect of removing the propane subsidy on the consumption of coal.

Results for the empirical application of accessibility theory to propane access can be used as energy access indicators. Sprawl measures, gravity model, and central place theory inform the energy access indicators computed in this paper. The energy access indicators account for country-specific and spatial characteristics using the demand for propane in Mexican households in 2014.

Table 8 summarises the results of the estimated demand equations for the different energy goods. We conducted Granger causality tests between income and expenditures in electricity, natural gas, propane, coal, and firewood to test for causality.

Table 8. Residential Demand Estimated Equations

\begin{tabular}{|c|c|c|c|c|c|}
\hline \multirow{2}{*}{ Variables } & Electricity & Natural Gas & Propane & Coal & Firewood \\
\hline & $5-\mathrm{I}$ & 5 -II & 5-III & 5-IV & $5-\mathrm{V}$ \\
\hline \multirow[t]{2}{*}{ Price } & $-7.27 * * *$ & $-0.95 * * *$ & $0.244 * * *$ & $-0.234 * * *$ & $0.176^{* * *}$ \\
\hline & $(-11.95)$ & $(-11.56)$ & $(12.16)$ & $(-2.854)$ & $(4.32)$ \\
\hline \multirow[t]{2}{*}{ REP } & $0.68 * * *$ & & $-0.113 * * *$ & $0.634 * *$ & \\
\hline & $(-0.54)$ & & $(-6.16)$ & (2.399) & \\
\hline \multirow[t]{2}{*}{ Income } & $0.44 * * *$ & $0.26^{* * *}$ & $0.204 * * *$ & 0.05 & $0.09^{* * *}$ \\
\hline & $(66.82)$ & $(21.96)$ & $(72.86)$ & $(2.331)$ & $(4.83)$ \\
\hline \multirow[t]{2}{*}{$R D$} & $-0.22 * * *$ & $-0.41 * * *$ & 0.002 & 0.287 & $0.24 * * *$ \\
\hline & $(-16.23)$ & $(-7.82)$ & $(0.38)$ & $(5.145)$ & $(7.56)$ \\
\hline \multirow[t]{2}{*}{ HHS } & $-0.002 * * *$ & 0.02 & $0.011^{* * *}$ & 0.018 & $0.07 * * *$ \\
\hline & -4.26 & $(1.05)$ & $(2.76)$ & $(0.528)$ & $(2.73)$ \\
\hline \multirow[t]{2}{*}{$E D U$} & $0.03 * * *$ & 0.02 & $-0.006^{*}$ & $-0.048 * *$ & $-0.09 * * *$ \\
\hline & -0.22 & $(1.54)$ & $(-1.73)$ & $(-1.519)$ & $(-3.94)$ \\
\hline \multirow[t]{2}{*}{$E A D$} & $0.13^{* * *}$ & -0.003 & $0.077 * * *$ & -0.105 & -0.07 \\
\hline & $(3.00)$ & $(-0.01)$ & $(2.97)$ & $(-0.584)$ & (20.19) \\
\hline \multirow[t]{2}{*}{ Const. } & $-6.82 * * *$ & 1.78 & $4.82 * * *$ & $5.786^{* * *}$ & $4.44 * * *$ \\
\hline & $(-9.05)$ & $(6.32)$ & $(108.4)$ & (13.89) & $(20.19)$ \\
\hline$N$ & 67886 & 4667 & 41123 & 1998 & 3562 \\
\hline$R^{2}$ & 0.3 & 0.13 & 0.12 & 0.02 & 0.03 \\
\hline
\end{tabular}

Note: $t$-statistics are in parenthesis.

* Statistically significant at $10 \%$ significance level.

** Statistically significant at $5 \%$ significance level.

*** Statistically significant at $1 \%$ significance level.

Table 9 shows the $F$-statistics for the Granger causality test. We analysed the $F$-statistics of regressing income against the expenditure on every energy good lagged one period. Then, we regressed the household expenditure on every energy good against the household income lagged one period. 
Table 9. Granger Causality Tests

\begin{tabular}{|cc|cl|}
\hline \multicolumn{2}{|c|}{ Expenditure $\rightarrow$ Income } & \multicolumn{2}{c|}{ Income $\rightarrow$ Expenditure } \\
& F-test & & \multicolumn{1}{c|}{ F-test } \\
\hline$Y_{t}=\beta_{0}+\beta_{1} Y_{t-1}+\beta_{2} Q_{i, t-1}^{\text {Electricity }}$ & $16.85^{* * *}$ & $Q_{i, t}^{E l e c}=\beta_{0}+\beta_{1} Q_{i, t-1}^{\text {Elec }}+\beta_{2} Y_{t-1}$ & $141.33^{* * *}$ \\
$Y_{t}=\beta_{0}+\beta_{1} Y_{t-1}+\beta_{2} Q_{i, t-1}^{N a t u r a l ~ G a s}$ & $18.25^{* * *}$ & $Q_{i, t}^{N G}=\beta_{0}+\beta_{1} Q_{i, t-1}^{N G}+\beta_{2} Y_{t-1}$ & $18.85^{* * *}$ \\
$Y_{t}=\beta_{0}+\beta_{1} Y_{t-1}+\beta_{2} Q_{i, t-1}^{L P G}$ & $15.13^{* * *}$ & $Q_{i, t}^{L P G}=\beta_{0}+\beta_{1} Q_{i, t-1}^{L P G}+\beta_{2} Y_{t-1}$ & $78.4^{* * *}$ \\
$Y_{t}=\beta_{0}+\beta_{1} Y_{t-1}+\beta_{2} Q_{i, t-1}^{\text {Coal }}$ & $10.48^{* * *}$ & $Q_{i, t}^{\text {Coal }}=\beta_{0}+\beta_{1} Q_{i, t-1}^{\text {Coal }}+\beta_{2} Y_{t-1}$ & 2.01 \\
$Y_{t}=\beta_{0}+\beta_{1} Y_{t-1}+\beta_{2} Q_{i, t-1}^{\text {Frewood }}$ & $15.81^{* * *}$ & $Q_{i, t}^{F W}=\beta_{0}+\beta_{1} Q_{i, t-1}^{F w}+\beta_{2} Y_{t-1}$ & $6.94 * * *$ \\
\hline
\end{tabular}

We computed Variance Inflation Factors (VIF) to test for multicolinearity between the variables in each equation. A VIF greater than 10 indicates multicolinearity. Except for REPI in the natural gas and firewood demand equations, all the variables did not show multicolinearity problems. Therefore, we dropped the REPI variable from Equations (6-II) and (6-V). Table 10 shows the VIF results for every equation.

Table 10. Variance Inflation Factors

\begin{tabular}{|l|c|c|c|c|c|}
\hline \multirow{2}{*}{ Variables } & Electricity & Natural Gas & Propane & Coal & Firewood \\
\cline { 2 - 6 } & $6-\mathrm{I}$ & 6 -II & 6 -III & 6 -IV & 6-V \\
\hline Price & 4.74 & 1.00 & 3.69 & 1.10 & 1.00 \\
\hline REP & 4.74 & & 3.68 & 1.09 & \\
\hline Income & 1.14 & 1.14 & 1.14 & 1.14 & 1.14 \\
\hline $\boldsymbol{R D}$ & 1.14 & 1.14 & 1.14 & 1.15 & 1.14 \\
\hline $\boldsymbol{H H S}$ & 1.00 & 1.00 & 1.00 & 1.00 & 1.00 \\
\hline $\boldsymbol{E D U}$ & 1.03 & 1.03 & 1.03 & 1.03 & 1.03 \\
\hline $\boldsymbol{E A D}$ & 1.04 & 1.04 & 1.04 & 1.04 & 1.04 \\
\hline
\end{tabular}

The electricity demand model has a Durbin Watson test of 2.02, indicating no autocorrelation. The goodness of fit suggests 84 times out of 100 of the variations of the dependent variable explained variations in the independent variable; therefore, data fit the model. All the variables are statistically significant at $99 \%$ except for REPI and the education of the householder.

The estimates of Equation (5-I) suggest when the price of electricity increases by $1 \%$, its demand decreases by $7.27 \%$, other things being equal. These results suggest that Mexico has a greater sensibility to changes in electricity prices than developed countries as the USA and Germany.

When the REPI for electricity increases by $1 \%$, the demand for electricity decreases by $0.68 \%$, other things being equal. These results suggest that natural gas, propane, coal, and firewood are complementary goods of electricity in Mexican households. Given the statistical insignificance of this variable, the results cannot be conclusive and should be taken with caution. Data quality for firewood might affect these results.

Mexican households perceive electricity as a normal good; when their income increases by $1 \%$, their demand for electricity increases by $0.44 \%$, ceteris paribus. 
Results suggest that electricity is a necessity good in Mexico because its demand increases less than proportionally when household income increases. The rural dummy and the electricity access dummy show the expected sign and are statistically significant. With the increase in the number of individuals at the household level, the demand for electricity increases, holding all the other factors constant. Education has the expected positive result. As the years of schooling go up, the demand for electricity, propane, and natural gas go up when all the other factors remain unchanged.

Equation (6-II) estimates the demand for natural gas in Mexican households. When natural gas price increases by $1 \%$, Mexican households demand $0.95 \%$ less natural gas, all other things being equal. When income increases by $1 \%$, the demand for natural gas increases by $0.26 \%$, behaving as a necessity good. The greater the household size, the lower the demand for natural gas. These results suggest that economies of scale appear to play a role in explaining the demand for natural gas in Mexican households. The higher the householder's education level, the greater the demand for natural gas.

The positive sign between the demand for propane and its price suggests simultaneity bias. Conversely, the propane market structure to electricity, natural gas, and coal behave as a monopolistic competitive good. The REPI suggests that propane is a complementary good to the rest of the energy sources. The income elasticity indicates that propane is a necessary good in Mexican households. The greater the household size, the lower the residential demand for propane. The higher the education level, the greater the propane demand in Mexico.

The firewood market has a similar market structure in Mexico. Even when a few firms control the market, supply factors are affecting the firewood market price. While estimating the demand equation for firewood, the results present simultaneity bias unless a simultaneous equation model is applied.

Results for the estimated coal demand equation showed the expected signs. When the price for coal increases by $1 \%$, its demand decreases by $0.23 \%$, holding all the other factors constant; therefore, coal is a price-elastic good. It behaves as a substitutive to other heating energy goods. The gradual liberalization of the propane subsidy may increase the reliance of households on coal and reduce the accessibility to modern energy goods in Mexican households.

Coal behaves like a normal good, the higher the income, the greater its demand. Increasing the household income by $1 \%$, the demand for coal increases by $0.009 \%$. The rural dummy variable indicates that households in rural areas tend to use more firewood than urban households, ceteris paribus.

The set of Equations (6) specifies the empirical measures of energy access using accessibility theory. The first approach uses propane storage tank availability to measure energy access. The sprawl approach uses distance to measure energy access. The gravity approach uses distance and propane capacity of the propane station to measure accessibility. The market area approach uses distance, capacity, and area of the census tract to address energy access. Table 11 summarises the results obtained from applying the different energy access measures to residential demand in Mexican households in 2014. 
Table 11. Energy Access Measures

\begin{tabular}{|c|c|c|c|c|c|c|c|c|c|c|}
\hline \multirow[t]{2}{*}{ Variables } & \multicolumn{2}{|c|}{$\begin{array}{c}\text { LPGA-Tank } \\
\text { (6-I) }\end{array}$} & \multicolumn{2}{|c|}{$\begin{array}{c}\text { LPGA-Distance } \\
\text { (6-II) }\end{array}$} & \multicolumn{2}{|c|}{$\begin{array}{c}\text { LPGA-Gravity } \\
\text { (6-III) }\end{array}$} & \multicolumn{2}{|c|}{$\begin{array}{c}\text { LPGA-Distance } \\
\text { (6-IVa) }\end{array}$} & \multicolumn{2}{|c|}{$\begin{array}{c}\text { LPGA-Distance } \\
\text { (6-IVb) }\end{array}$} \\
\hline & Coeff & $t$-stat & Coeff & $t$-stat & Coeff & $t$-stat & Coeff & $t$-stat & Coeff & $t$-stat \\
\hline Constant & $4.35^{* * *}$ & 3.94 & $3.885^{* * *}$ & 11.70 & $6.038^{* * *}$ & 9.42 & $5.33 * * *$ & 8.38 & $6.614^{* * *}$ & 8.29 \\
\hline Income14 & $0.201 * * *$ & 6.87 & $0.227 * * *$ & 7.85 & $0.212 * * *$ & 7.35 & $0.222 * * *$ & 7.81 & $0.211 * * *$ & 7.24 \\
\hline HHS & -0.006 & -0.14 & -0.006 & -0.15 & -0.006 & -0.14 & $-0.017 * *$ & -0.39 & -0.009 & -0.22 \\
\hline Edu & $0.079 *$ & & $0.106^{* *}$ & 2.28 & 0.071 & 1.53 & $0.109 * *$ & 2.34 & $0.092 * *$ & 1.97 \\
\hline LPGAD & $0.224 * * *$ & 2.78 & & & & & & & & \\
\hline Dist & & & $-0.049 * * *$ & -2.92 & $-0.045^{* * *}$ & -2.66 & $-0.116^{* *}$ & -2.87 & $-0.144 * * *$ & -3.15 \\
\hline Cap & & & & & $-0.132 * * *$ & -3.01 & $0.123 * * *$ & 3.72 & & \\
\hline HHU & & & $0.146^{* * *}$ & 3.90 & & & & & & \\
\hline Pop & & & & & & & & & $-0.066^{* * *}$ & -1.55 \\
\hline Area & & & & & & & 0.793 & 0.36 & 0.054 & 1.44 \\
\hline$N$ & 600 & & 60 & & 600 & & 60 & & 6 & \\
\hline$R^{2}$ & 0.10 & & 0.1 & & 0.1 & & 0. & & 0.1 & \\
\hline
\end{tabular}

A cross-sectional analysis was a viable approach to compute the energy access empirical measures because of data constraints on regional prices for the energy goods and geographical data. The demand equation for propane in 2014 had no regional prices; therefore, we found perfect multicolinearity in the price for propane and the REPI variables. We omitted those variables from the cross-sectional analysis, as in Salari and Javid (2017).

Equation (6-I) estimates the propane demand equation using a dummy variable that denotes whether the household has a propane storage tank as a measure of energy access. The interpretation of this indicator is straight forward: an increase in the storage tank availability at the household level increases their demand for propane. Income, education of the householder, and household size show the expected sign.

When the household income increases by $1 \%$, its demand for propane increases by $0.201 \%$. This result suggests that propane is a necessary good in Mexican households. When the householder's education increases by $1 \%$, their propane demand increases by $0.079 \%$. When the size of the household increases by $1 \%$, its demand for propane decreases by $0.006 \%$, possibly because of the effect of economies of scale. Except for the household size, all the variables are statistically significant at $10 \%$.

Equation (6-II) corresponds to the sprawl approach to accessibility, and it uses distance as an energy access indicator. Distance shows the expected sign. The further the distance from the propane station to the census tract, the lower the propane demand. The farther the household from the propane station, the lower the energy access, and the lower its demand for propane. The household propane demand decreases by $0.049 \%$, when the closest propane is $1 \%$ farther from the household census tract, all the other things being equal. 
Equation (6-III) applies the gravity model to energy access using Torrens (2000) and Torrens and Albertani (2000) approach. The higher the household income, the more attracted the propane station to make trips. The positive sign in household income supports this argument.

The greater the production capacity of propane station, the lower its incentive to make trips. When the production capacity of the closest propane station increases by $1 \%$, the household consumption decreases by $0.132 \%$.

The distance between the household $i$ and propane station discourages longdistance trips; hence, the negative sign of the estimated coefficient for the distance variable is as expected.

Adding up the coefficients of the distance, capacity, and income variables gives an energy access indicator, which is theoretically informed by the gravity model. The result suggests the expected positive (0.033); the greater the accessibility, the higher the household demand for propane.

Equations (6-IVa) and (6-IVb) apply the market area concept to energy access. The variables that correspond to the maximum capacity of the propane station show the expected sign. The higher the production capacity of the propane station, the lower its incentive to conduct trips to the household; therefore, its sign is negative. Results for Equation (6-IVa) show when the installed capacity of the propane station increases by $1 \%$, the propane demand decreases by $0.11 \%$, all other things being equal.

The installed capacity effect becomes stronger when using population instead of housing units as Equation (6-IVb) shows. An increase in the propane installed capacity by $1 \%$ decreases the propane demand by $0.14 \%$. HHU refers to the number of housing units per census tract and it showed the expected positive sign. When the housing units increases by $1 \%$, the propane demand increases by $0.02 \%$. When using population instead of housing units, the expected sign does not hold.

The AREA variable refers to the area of the census tract of the surveyed household. We expected to find a negative value; however, in both specifications, the greater the area of the census tract, the higher the propane demand, the greater the accessibility. An increase in the census tract area by $1 \%$ leads to an increase in the propane demand by $0.123 \%$ (Equation (6-IVa)). Results for Equation (6-IVb) suggest that the propane demand increases by $0.05 \%$ when the census tract area increases by $1 \%$.

Policy targets of developing countries seeking to improve household access to energy should encompass the reduction of coal and firewood. Furthermore, applying accessibility theory can contribute to policymaking decisions. The demand estimates of energy goods can be used to complement energy access indicators informed by accessibility theory in developing countries. Accessibility theory holds when applied to Mexican household data in 2014.

\section{CONCLUSION}

The energy access concept encompasses the access of households to electricity, natural gas, and propane and the extent of their reliance on coal and firewood (Balachandra, 2011; Pachauri et al., 2012). 
This paper has computed theoretically informed energy access measures to determine whether accessibility theory holds when they are applied to the demand for propane in Mexican households, and it has estimated residential demand equations of different energy goods. Results are limited due to data availability as other authors work on estimating residential energy demand using developing countries data. However, it represents an attempt to integrate accessibility theory and policy analysis. The empirical model can be used by developing countries to make energy policy decisions accounting for country-specific demand factors.

The residential energy demand has been extensively studied in the literature for developing and developed countries. Energy access is identified as the most significant factor in the demand for energy. Energy access in developing countries consists of access to electricity, natural gas, and propane and of reducing the consumption of traditional fuels such as coal and firewood.

Aside from Islas (2013), this paper is one of the first empirical studies using microdata in Mexico to estimate elasticity of different energy goods. Our results are similar to those found in the upper limit of the survey conducted by Al-Sahlaui (1989) for natural gas demand-price elasticity of -0.95 . In addition, our electricity demand-price elasticity is higher than the elasticity estimated in the rest of the papers consulted; as such, Bohi and Zimmerman (1984) reported a demand-price elasticity of electricity of -4.56 in their survey upper limit.

Other authors estimated demand-price elasticity for traditional energy sources such as kerosene in Indonesia (Fitzgerald, Barnes, \& McGranahan, 1990) at -0.11, while Labandeira et al. (2017) calculated an average demand-price elasticity of heating oil of -0.017 in their elasticity surveys. Price elasticity of firewood and coal is yet to be estimated in other developing countries as traditional energy goods consumed in Mexico vary with those consumed in other developing countries.

This paper fills the gap in literature and opens the door for more research in the energy demand area with applications of accessibility theory by empirically estimating different energy goods using household data from 2008 to 2014, and the application of the REPI.

Accessibility theory holds when applied to the demand for propane in Mexican household data in 2014. The estimates of the demand for propane that correspond to the energy access indicators informed by the accessibility theory were statistically significant and showed the expected signs. The estimated demand equations and the price elasticity can be used to evaluate the effect of removing modern energy subsidies on the consumption of firewood and coal.

The energy policy agenda in Mexico focuses on energy efficiency because the Mexican government and international agencies consider that the country has complete energy access. The current energy access indicators computed by the national and international agencies consider legal frameworks and access to electricity but overlook the reliance that households have on firewood and coal. Even when the Mexican government implemented the energy reform in 2014, the access to energy was not perceived as a priority.

The energy reform in Mexico should prioritize energy access at the household level, and therefore it should implement measures to reduce the consumption of coal and firewood. Improving the energy access and empirical estimations of coal 
and firewood demand equations are helpful in assessing the performance in energy access terms. Investment in energy access indicators as well as in data quality improvements to empirically estimate energy access indicators is a policy recommendation that comes after this research.

\section{REFERENCES}

Al-Sahlawi, M. A. (1989). The Demand for Natural Gas: A Survey of Price and Income Elasticities. The Energy Journal, 10(1), 77-90. https://doi.org/10.5547/ISSN0195-6574-EJ-Vol10-No1-7

Balachandra, P. (2011). Dynamics of Rural Energy Access in India: An Assessment. Energy, 36(9), 5556-5567. https://doi.org/10.1016/j.energy.2011.07.017

Banerjee, S. G., Moreno, F. A., Sinton, J., Primiani, T., \& Seong, J. (2017). Regulatory Indicators for Sustainable Energy: A Global Scorecard for Policy Makers. World Bank Report. RISE. Retrieved from http://hdl.handle.net/10986/26099

Barnes, D. F., \& Qian, L. (1992). Urban Interfuel Substitution, Energy Use, and Equity in Developing Countries: Some Preliminary Results. World Bank, 1-38. https://www.researchgate.net/publication/5077912_Urban_Interfuel_Substitution_Energy_Use _and_Equity_in_Developing_Countries

Barnes, D. F., Krutilla, K., \& Hyde, W. (2004). The Urban Household Energy Transition Energy, Poverty, and the Environment in the Developing World. World Bank, 1-112. https://www.esmap.org/sites/esmap.org/files/Rpt_UrbanEnergyTransition.pdf

Becker, G. S. (1992). Fertility and the Economy. Journal of Population Economics, 5, 185-201. https://doi.org/10.1007/BF00172092

Becker, G. S. (2009). A Treatise on the Family. Harvard University Press.

Bohi, D., \& Zimmerman, M. B. (1984). An Update on Econometric Studies of Energy Demand Behavior. Annual Review of Energy, 9(1), 105-154. https://doi.org/10.1146/annurev.eg.09.110184.000541

Bosch-Domènech, A. (1991). Economies of Scale, Location, Age, and Sex Discrimination in Household Demand. European Economic Review, 35(8), 1589-1595. https://doi.org/10.1016/0014-2921(91)90020-J

Deaton, A., \& Paxson, C. (1998). Economies of Scale, Household Size, and the Demand for Food. Journal of political economy, 106(5), 897-930. Retrieved from http://www.jstor.org/stable/2991489?origin=JSTOR-pdf

Eakins, J. (2013). An Analysis of the Determinants of Household Energy Expenditures: Empirical Evidence from the Irish Household Budget Survey (Publication No. AAT 27558477) [Doctoral dissertation, University of Surrey]. ProQuest Dissertations and Theses

FAO. (1987). Food and Agricultural Organization, Simple Technologies for Charcoal Making. FAO Forestry Paper 41. Retrieved from http://www.fao.org/docrep/X5328S/X5328S19.htm

FAO. (n. d.). FAO Food Price Index. Food and Agricultural Organization. Retrieved from http://www.fao.org/worldfoodsituation/foodpricesindex/en/

FAOSTAT. (2021). Wood Fuel, All Species (Export/Import, 1961-2016). Retrieved from http://www.fao.org/faostat/en/\#data/FO

Fisher, F. M., \& Kaysen, C. (1962). A Study in Econometrics: The Demand for Electricity in the United States. North-Holland Pub. Co.

Fitzgerald, K. B., Barnes, D., \& McGranahan, G. (1990). Interfuel Substitution and Changes in the Way Households Use Energy: The Case of Cooking and Lighting Behavior in Urban Java. World Bank, 1-36. http://documents1.worldbank.org/curated/en/550711468766173507/pdf/multipage.pdf

Georgia Department of Agriculture. (n. d.). Geprgia Poltry: Statistics \& Market Prices, Data, Graphs, Weekly Newsletter. Retrieved from http://agr.georgia.gov/historical-data.aspx

Glaeser, E. L., \& Kahn, M. E. (2004). Sprawl and Urban Growth. In V. Henderson \& J. F. Thisse (Eds.), Handbook of Regional and Urban Economics (vol. 4, pp. 2481-2527). North Holland.

Hahn, E. (2019). El Gas, Propane Gas Blog, Propane Conversions: Gas kg, Litres, MJ, kWh \& $\mathrm{m}^{3}$. Available from http://www.elgas.com.au/blog/389-lpg-conversions-kg-litres-mj-kwh-and-m3 
Head, K. (2003). Gravity for Beginners. University of British Columbia.

Heltberg, R. (2005). Factors Determining Household Fuel Choice in Guatemala. Environment and Development Economics, 10(3), 337-361. https://doi.org/10.1017/s1355770x04001858

Hosier, R. H., \& Dowd, J. (1987). Household fuel choice in Zimbabwe: An empirical test of the energy ladder hypothesis. Resources and Energy, 9(4), 347-361. https://doi.org/10.1016/01650572(87)90003-X

INEGI. (2015a). Encuesta Nacional de Ingreso y Gasto de los Hogares 2014. Retrieved from http://www.inegi.org.mx/est/contenidos/proyectos/encuestas/hogares/regulares/enigh/enigh201 4/tradicional/default.aspx

INEGI. (2015b). Geographic Area, Rural and Urban, Urban and Rural Geo-Statistical Cartography by Block. Retrieved from http://www.beta.inegi.org.mx/app/mapas/

Islas, C. C. I. (2013). Energy Consumption of Mexican Households. The Journal of Energy and Development, 38, 189-219. http://www.jstor.org/stable/24813066

Jones, R. H. (2010). Energy Poverty: How to Make Modern Energy Access Universal? Joint report. Special early excerpt of the World Energy Outlook.

Labandeira, X., Labeaga, J. M., \& López-Otero, X. (2017). A Meta-Analysis on the Price Elasticity of Energy Demand. Energy Policy, 102, 549-568. https://doi.org/10.1016/j.enpol.2017.01.002

Lakshmanan, T. R., \& Anderson, W. (1980). Residential Energy Demand in the United States: A Regional Econometric Analysis. Regional Science and Urban Economics, 10(3), 371-386. https://doi.org/10.1016/0166-0462(80)90038-1

Masera, O. R., Saatkamp, B. D., \& Kammen, D. M. (2000). From Linear Fuel Switching to Multiple Cooking Strategies: A Critique and Alternative to the Energy Ladder Model. World Development, 28(12), 2083-2103. https://doi.org/10.1016/S0305-750X(00)00076-0

Mexican Geological Service. (2017). Mining, Value of Coal Production. Retrieved from http://portalweb.sgm.gob.mx/economia/es/produccion-minera/carbon.html

Missouri Department of Agriculture. (2017). Missouri Weekly Weighted Average Feeder Cattle Report. Retrieved from https://www.ams.usda.gov/mnreports/jc 1s795.txt

Mount, T. D., Chapman, L. D., \& Tyrrell, T. J. (1973). Electricity Demand in the United States: An Econometric Analysis. No. ORNL-NSF-EP--49; CONF-730205--5.

Nicholson, W., \& Snyder, C. (2011). Microeconomic Theory: Basic Principles and Extensions. Nelson Education.

Nordhaus, W. D. (1973). World Dynamics: Measurement Without Data. The Economic Journal, 83(332), 1156-1183. https://doi.org/10.2307/2230846

O’Neill, B. C., \& Chen, B. S. (2002). Demographic Determinants of Household Energy Use in the United States. Population and Development Review, 28, 53-88. https://www.jstor.org/stable/pdf/3115268.pdf

O’Sullivan, A. (2005). Market Areas and Central Place Theory.

Pachauri, S. (2004). An Analysis of Cross-Sectional Variations in Total Household Energy Requirements in India Using Micro Survey Data. Energy Policy, 32(15), 1723-1735. https://doi.org/10.1016/S0301-4215(03)00162-9

Pachauri, S., Rao, N. D., Nagai, Y., \& Riahi, K. (2012). Access to Modern Energy: Assessment and Outlook for Developing and Emerging Regions. Laxenburg: IIASA.

Poulsen, M. F., \& Forrest, J. (1988). Correlates of Energy Use: Domestic Electricity Consumption in Sydney. Environment and Planning A, 20(3), 327-338. https://doi.org/10.1068/a200327

Reddy, S. (2015). Measuring and Evaluating Energy Security and Sustainability. Indira Gandhi Institute of Development Research, 1-35. http://www.igidr.ac.in/pdf/publication/WP-201508.pdf

Salari, M., \& Javid, R. J. (2016). Residential Energy Demand in the United States: Analysis Using Static and Dynamic Approaches. Energy Policy, 98, 637-649. https://doi.org/10.1016/j.enpol.2016.09.041

Salari, M., \& Javid, R. J. (2017). Modeling Household Energy Expenditure in the United States. Renewable and Sustainable Energy Reviews, 69, 822-832. https://doi.org/10.1016/j.rser.2016.11.183 
Sancho-Tomás, A., Sumner, M., \& Robinson, D. (2017). A Generalised Model of Electrical Energy Demand from Small Household Appliances. Energy and Buildings, 135, 350-366. https://doi.org/10.1016/j.enbuild.2016.10.044

Schipper, L. J., Haas, R., \& Sheinbaum, C. (1996). Recent Trends in Residential Energy Use in OECD Countries and Their Impact on Carbon Dioxide Emissions: A Comparative Analysis of the Period 1973-1992. Mitigation and Adaptation Strategies for Global Change, 1(2), 167-196. https://doi.org/10.1007/bf00455058

Schuler, A., Weber, C., \& Fahl, U. (2017). Energy Consumption for Space Heating of West-German Households: Empirical Evidence, Scenario Projections and Policy Implications. Energy Policy, 28(12), 877-894. https://doi.org/10.1016/S0301-4215(00)00074-4

Schulte, I., \& Heindl, P. (2017). Price and Income Elasticities of Residential Energy Demand in Germany. Energy Policy, 102, 512-528. https://doi.org/10.1016/j.enpol.2016.12.055

SENER (Ministry of Energy). (2016). 2015 National Energy Balance. Retrieved from https://www.gob.mx/cms/uploads/attachment/file/248570/Balance_Nacional_de_Energ_a_201 5 2_.pdf

Taylor, L. D. (1975). The Demand for Electricity: A Survey. The Bell Journal of Economics, 6(1), 74-110. https://doi.org/10.2307/3003216

The World Bank. (2017). Commodity Markets Outlook, Commodity Price Index, Agriculture Price Index. Retrieved from: http://pubdocs.worldbank.org/en/174381493046968144/CMO-April2017-Full-Report.pdf

Torrens, P. \& Alberti, M. (2000). Measuring Sprawl. CASA Working Paper 27. London, UK: Centre for Advanced Spatial Analysis, University College London. Retrieved from http://www.casa.ucl.ac.uk/working_papers.htm

Torrens, P. (2000). How Land-Use-Transportation Models Work. CASA Working Paper 20. London, UK: Centre for Advanced Spatial Analysis, University College London. http://www.casa.ucl.ac.uk/working_papers.htm

United Nations (UN). (n. d.). Sustainable Development Goals, 17 Goals to Transform our World. Available from https://www.un.org/sustainabledevelopment/energy/

US Census Bureau. (2007). Geography, 2010 Census Urban Areas FAQs, Urban and Rural Definition. https://www.census.gov/geo/reference/ua/uafaq.html

\section{AUTHORS' SHORT BIOGRAPHIES}

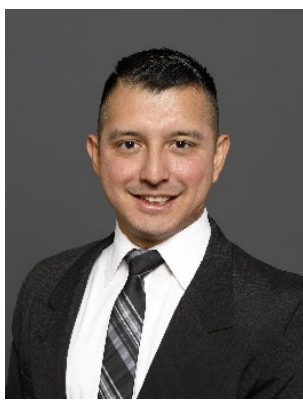

Rafael Perez is a Research Economist at the Hunt Institute for Global Competitiveness at the University of Texas at El Paso (UTEP) located at Kelly Hall Building, Suite 414, El Paso, Texas, USA 79968. He received a Doctor of Economics degree from New Mexico State University (NMSU) in 2017. Rafael received the Master's degree in Applied Economics from the Northern Border College and the Bachelor's degree in Economics from University Autonomous of Ciudad Juarez. Before joining UTEP, Rafael worked as a Business Data Analyst in the private sector and as a Research Assistant at NMSU. Research interests: Economic development, energy economics, international economics, and agricultural economics.

E-mail: rperezpena@utep.edu

ORCID iD: https://orcid.org/0000-0003-1511-5540 


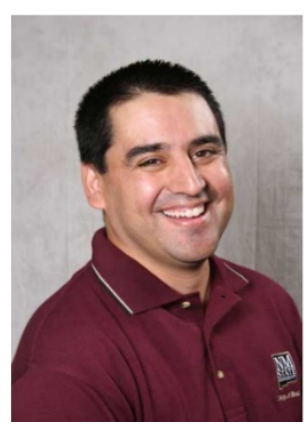

Benjamin Widner is a Professor at the Department of Economics, Applied Statistics \& International Business at NMSU located at 1780 E University Ave, Las Cruces, NM 88003, United States Guthrie Hall, BC 315. He received a $\mathrm{PhD}$ in Economics from Colorado State University in 2005. Benjamin received the Master's degree in Economic Policy Analysis and the Bachelor's degree in Business Administration from NMSU. While at NMSU, Benjamin worked as a Visiting Professor at Aleksandër Moisiu University and as an Assistant Director at the Center for Economic and Personal Finance Education. Research interests: Urban/regional economics, public finance, microeconomics, development, econometrics, managerial economics, and environmental economics.

E-mail: bwidner@nmsu.edu

ORCID ID: https://orcid.org/0000-0002-3202-2218 